\title{
Analisis Perilaku Organisasi dalam Melaksanakan Kegiatan Akreditasi Secara Daring di Fakultas Keguruan dan Ilmu Pendidikan (FKIP) Universitas Muhammadiyah Palembang
}

\author{
Sri Utami ${ }^{1}$, Akmal Hawi ${ }^{2}$, Maryamah ${ }^{3}$ \\ 1,2,3 Universitas Islam Negeri Raden Fatah Palembang, Indonesia \\ sriutami046@gmail.com \\ akmalhawi123@gmail.com \\ maryamah_uin@radenfatah.ac.id
}

\begin{abstract}
To analyze it, the research was conducted with the following problem formulations: (1) How is organizational behavior in preparation, during implementation, and after the performance of Online Accreditation activities in the Education Administration Study Program? (2) What factors influence the organizational behavior in carrying out Online Accreditation activities in the Education Administration Study Program?. This study aims: (1) To analyze how organizational behavior is in preparation, during implementation, and after implementing Online Accreditation activities. (2) To analyze what factors influence the organizational behavior in carrying out Online Accreditation activities. The research method uses qualitative research with data collection techniques through participatory observation, in-depth interviews, and documentation. Data analysis is carried out continuously from data collection to writing as part of the triangulation process. From this research, findings were obtained regarding: (1) At the preparation stage, forming a formulation team, division of tasks and responsibilities, teamwork, motivation, work control, extra physical and mental preparation, and loyalty of organizational members. (2) The implementation process is a sense of worry, synchronization of data on Form 3A (Study Program) and Form 3B (Faculty), facilities and infrastructure for Online, Tashporce, and involvement of various related parties during Field Assessments. (3) After implementation, namely performance evaluation, improvement of data, and obtaining results. (4) Supporting factors are selecting team members, leadership, socialization, quality of the work environment, advanced technology, and the advantages of the Online system. (5) Inhibiting factors are egoism, lack of trust, lack of coordination, incomplete awards, lack of facilities and infrastructure, limited time, physical evidence of documents, and sudden cancellation of attendance by the parties involved. Based on the research results, there are several suggestions: (1) The Education Administration Study Program must maintain the quality of the Accreditation results and be an example for other Study Programs at Muhammadiyah University of Palembang, other State and Private Universities. (2) Can maintain and improve the quality of individuals involved in Accreditation activities, and the work of the Accreditation Form Team can be an example for Higher Education Leaders anywhere.
\end{abstract}

Keywords: organizational behavior, online accreditation 
ABSTRAK

Penelitian ini bertujuan: (1) Untuk menganalisis bagaimana perilaku organisasi dalam persiapan, saat pelaksanaan dan setelah pelaksanaan kegiatan Akreditasi secara Daring. (2) Untuk menganalisis faktor-faktor apa saja yang mempengaruhi perilaku organisasi dalam melaksanakan kegiatan Akreditasi secara Daring. Metode penelitian yang digunakan adalah penelitian kualitatif dengan teknik pengumpulan data melalui observasi partisipatif, wawancara mendalam dan dokumentasi. Analisis data juga dilakukan secara terus menerus sejak pengumpulan data hingga penulisan, sebagai bagian dari proses trianggulasi. Dari penelitian ini, diperoleh temuan-temuan tentang: (1) Pada tahap persiapan yaitu dibentuknya tim perumus, pembagian tugas dan tanggung jawab, kerjasama tim, motivasi, kontrol kerja, persiapan fisik dan mental ekstra, serta loyalitas anggota organisasi. (2) Porses pelaksanaan yaitu adanya rasa khawatir, kesingkronan data pada Borang 3A (Program Studi) dan Borang 3B (Fakultas), sarana dan prasarana untuk Daring, Tashporce, serta keterlibatan berbagai pihak terkait saat Asesmen Lapangan. (3) Setelah pelaksanaan yaitu evaluasi kinerja, perbaikan data dan perolehan hasil. (4) Faktor pendukung yaitu pemilihan anggota tim, kepemimpinan, sosialisasi, kualitas lingkungan kerja, teknologi canggih dan keuntungan dari sistem Daring. (5) Faktor penghambat yaitu egoisme, tidak amanah, kurangnya koordinasi, penghargaan tidak terinci, kurangnya sarana dan prasarana, keterbatasan waktu, bukti fisik dokumen, serta pembatalan hadir secara mendadak oleh pihak terlibat. Berdasarkan hasil penelitian, terdapat beberapa saran sebagai berikut: (1) Program Studi Administrasi Pendidikan harus mampu mempertahankan kualitas dari perolehan hasil Akreditasi dan bisa menjadi contoh untuk Program Studi lainnya yang ada di Universitas Muhammadiyah Palembang dan Perguruan Tinggi Negeri serta Swasta lainnya. (2) Dapat menjaga dan meningkatkan kualitas individu yang dilibatkan pada kegiatan Akreditasi dan kerja Tim Borang Akreditasi dapat menjadi contoh untuk Pimpinan Perguruan Tinggi dimanapun.

Kata kunci: perilaku organisasi, akreditasi secara daring 


\section{PENDAHULUAN}

Dalam mengkaji sebuah pemahaman mengenai perilaku organisasi berarti terdapat beberapa hal untuk mengetahui bagaimana perilaku anggota organisasi, yaitu perilaku individu maupun kelompok. Karena perilaku organisasi adalah ilmu perilaku individu dan dikembangkan berpusat pada tingkah laku manusia didalam organisasi. Sebuah perilaku dalam organisasi merupakan studi pembahasan tentang aspek-aspek tingkah laku manusia dalam sebuah organisasi ataupun kelompok (Miftha Thoha, 2004). Perkembangan dunia yang terjadi saat ini, telah disadari ataupun tidak, manusia selalu berhubungan dengan berbagai macam orang yang memiliki karakter berbeda dan akan saling membutuhkan antar mereka dari berbagai segi kehidupan. Oleh sebab itu, manusia ialah penggerak utama pada setiap kegiatan di sebuah organisasi dan perilaku manusia akan menjadi peran yang sangat penting saat melakukan tugas dan tanggung jawab didalam organisasi. Perilaku organisasi adalah hasil dari interaksi antara individu dalam sebuah organisasi dan untuk memahami perilaku tersebut harus diketahui dahulu siapa individu yang menjadi pendukung di organisasi tersebut (Miftha Thoha, 2004). Hal inilah yang akan menjadikan karakteristik dari setiap individu ketika berinteraksi dengan sebuah karakteristik organisasi yang akan mewujudkan sebuah perilaku individu di dalam organisasi (Arifin Tahir, 2014).

Berkaitan dengan penjelasan diatas, dalam hal ini sejalan dengan apa yang difirmankan oleh Allah Swt dalam Q.S. Al-Hujurat:10, yaitu:

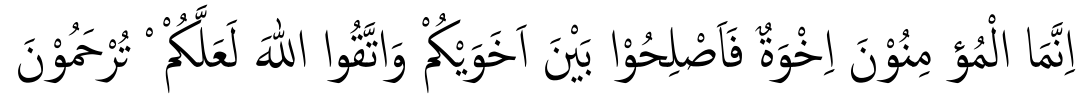

"Sesungguhnya orang-orang yang beriman itu bersaudara. Karena itu maka damaikanlah antara kedua saudaramu dan bertakwalah kepada Allah swt. supaya kamu mendapat rahmat".

Dari penjelasan Al-Qur'an diatas, dapat diambil pemahaman bahwa Islam juga mengajarkan dalam menjalani kehidupan sejatinya tidak akan mampu untuk dijalankan secara sendiri. Manusia tentunya tidak akan sanggup untuk menjalani kehidupan sewajarnya jika tidak ada bantuan dari sesama dan penting mengetahui bahwa terdapat orang lain selain dirinya sendiri di dunia.

Perilaku organisasi juga merupakan sebuah cara untuk membuat setiap orang yang berada disebuah organisasi ini terbiasa bekerjasama. Tentunya sebuah organisasi dari berbagai jenisnya, dapat dikatakan bahwa setiap individu melakukan interaksi dengan lingkungan internal dan eksternal. Beberapa hal yang terdapat dalam perilaku individu dalam berorganisasi ialah perilaku yang dapat terarah, terampil, terdidik, cakap, disiplin, 
kreatif, tekun, berpikir idealis, pekerja keras, fisik/mental yang kuat, setia dengan cita-cita dan sebuah tujuan di organisasi (Arif Yusuf Hamali, 2018). Tujuan itu terutama berkaitan dengan hal kemajuan "progress" organisasi untuk pencapaian hal-hal yang akan menjadi tolak ukur utama keberhasilan dari organisasi tersebut. Salah satu organisasi penting yang dibentuk pada Perguruan Tinggi baik di Negeri ataupun Swasta ialah organisasi untuk mengurus pelaksanaan Akreditasi. Akreditasi dikatakan penting karena hal tersebut ialah sebuah proses penilaian yakni kualitas yang ada di Institusi seperti pada Perguruan Tinggi manapun (Khoirunnisa Eva, 2018). Peraturan Menteri Riset, Teknologi dan Pendidikan Tinggi Republik Indonesia Nomor 32 Tahun 2016, menjelaskan bahwa akreditasi yaitu sebuah proses penilaian menentukan sebuah kelayakan dari Program Studi dan juga Perguruan Tinggi. Program studi merupakan bagian dari pelaksanaan sebuah kegiatan akademik yang melakukan pembelajaran pendidikan secara professional oleh ahlinya dan ketika telah memenuhi persyaratan, mereka dapat melaksanakan pendidikan program sarjana dan pascasarjana dalam berbagai bidang ilmu pengetahuan (Yulianingsih Yuyun, 2017). Untuk mempertahankan atau bahkan meningkatkan kualitasnya di program studi ini harusnya terdapat pelaksanaan kegiatan reakreditasi sesuai dengan jadwal pada peraturan yang telah dibuat oleh pemerintah. Dalam penyusunan borang tersebut sangat dibutuhkan sebuah organisasi dan harus dibentuk dalam sekala mikro/kecil dan/atau biasa disebut dengan Tim Borang Akreditasi yang terdiri dari individu-individu yang unggul dan cekatan untuk memperhatikan semua peraturan, ketentuan serta telah ditentukan oleh Badan Akreditasi Nasional Perguruan Tinggi atau lebih dikenal dengan singkatan BAN-PT.

Pembentukan sebuah organisasi berupa Tim Borang Akreditasi yang mana di dalamnya akan dilibatkan beberapa orang untuk melaksanakan kegiatan akreditasi yang telah terjadwal sebelumnya oleh BAN-PT demi menjaga serta meningkatkan kualitas mutu program studi di Perguruan Tinggi tersebut. Pelaksanaan akreditasi biasanya dilakukan dengan prosedur mendatangkan secara langsung Tim Asesor ke lokasi Perguruan Tinggi, tetapi terhitung sejak Maret 2019 dalam hal ini semua peraturan diubah, karena adanya pandemi Covid-19 yang hampir semua negeri di belahan dunia terjangkit oleh penyakit tersebut. Selama pandemi Covid-19 Pemerintah membuat peraturan untuk physical distancing terhadap alat trasnportasi dan ini bertujuan untuk pencegahan dari penyebaran Covid-19. Sementara itu, Perguruan Tinggi telah menunggu untuk proses dan hasil asesmen akreditasi sebagai tanggung jawab ke publik, serta dapat melindungi akan hal penting bagi mahasiswa dan masyarakat. Berkaitan dengan kondisi dan untuk meminimalisir penyebaran 
virus yang terjadi, BAN-PT membuat kebijakan baru dalam proses pelaksanaan Asesmen Lapangan ini. Ketetapan pada Pasal I angka I di Peraturan BAN-PT Nomor 5 Tahun 2020, adanya sebuah keputusan untuk pelaksanaan Asesmen Lapangan dilakukan dengan cara Daring dan juga telah menyusun Panduan Asesmen Lapangan secara Daring sesuai dengan semua kebutuhan dan kriteria penilaian yang telah terdapat di dalam instrumen akreditasi. Berkaitan pada pembahasan diatas, hal-hal tersebut menjadi daya tarik bagi penulis untuk diangkat dalam sebuah penelitian dan membahas tentang Analisis Perilaku Organisasi dalam Melaksanakan Kegiatan Akreditasi secara Daring pada Program Studi Administrasi Pendidikan di Fakultas Keguruan dan Ilmu Pendidikan (FKIP) Universitas Muhammadiyah Palembang.

\section{TINJAUAN PUSTAKA}

\section{Hakikat Perilaku Organisasi}

Hakikatnya perkembangan ilmu tentang perilaku sebuah organisasi dirasakan telah signifikan dan akhir-akhir ini juga terbilang banyak dibahas oleh manusia yang terlibat secara langsug ataupun tidak. Pembahasan mengenai hal tersebut bukan hanya terdapat dikalangan akademisi saja, tetapi pada kenyataannya juga dibicarakan oleh para politisi dan bahkan birokrasipun juga membahas hal serupa. Hal tersebut disadari, karena dalam pembahasan mengenai perilaku organisasi ini selain mudah untuk dipahami, pada kenyataannya terdapat permasalahan organisasi yang dianggap semakin ribet serta ditambah dengan manusia yang memiliki bermacam sifat maupun karakter dan menjadi sebuah tantangan utama oleh setiap pimpinan organisasi, baik organisasi pemerintah maupun swasta.

Adanya sebuah pendekatan dalam beroraganisasi berarti mempertaruhkan bahwasannya individu di organisasi ialah sebagai unsur yang terbilang kompleks dan tumbuhlah sebuah kebutuhan untuk memahami mengenai hal tersebut, serta harus didukung oleh sebuah penelitian sebelum dapat diterapkan untuk individu-individu secara efektif. Hal inilah yang menjadi pendukung sebuah pengertian yakni banyaknya permasalahan tentunya terdapat berbagai sebab dan akibat, pada akhirnya dibutuhkan sebuah tindakan untuk menyelesaikan permasalahan yang terfokus dalam situasi dan juga kondisi yang ada. Berkaitan dengan hal tersebut, terdapat difirman Allah S.W.T. pada Q.S. Al-Syuura:13 menjelaskan bahwa:

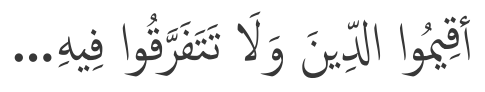




\section{"Tegakkanlah agama dan janganlah kamu berpecah belah tentangnya..."}

Dapat diartikan bahwasannya dalam sebuah organisasi tentu akan adanya persoalanpersoalan yang terjadi antar individu dalam berorganisasi. Tetapi persoalan yang ada dapat dijadikan setiap pembelajaran dan evaluasi untuk setiap individu dan organisasi kedepannya. Untuk dapat memahami tentang perilaku di organisasi, sebaiknya dipahami lebih dulu karakter anggota yang berperan sebagai penggerak dari organisasi. Kepentingan manusia yang juga beranekaragam jenisnya dan juga dapat menyentuh seluruh aspek kehidupan yang akan mendorong manusia untuk membentuk sebuah organisasi kerja, karena mempunyai kepentingan dalam memperoleh penghasilan guna memenuhi kebutuhan hidupnya.

Ada juga yang beranggapan bahwa perbedaan kemampuan yang dimiliki individu jelas berbeda, karena disebabkan sedari dilahirkan manusia tersebut memiliki sebuah takdir yang tentunya berbeda perihal keunggulan dalam suatu hal. Tetapi ada asumsi lain yakni bukan karena sejak dilahirkan, tetapi individu memiliki ketidaksamaan ketika saat mendapatkan sebuah informasi dari berbagai hal. Terlepas dari hal itu, setuju ataupun tidak dari pernyataan tersebut, ternyata dari kemampuan seseorang dapat digunakan ketika memprediksi sebuah kegiatan, serta hasil dai pekerjaan seseorang yang bekerjasama di organisasi.

Dari Sayyidina Ali bin Abi Thalib juga mengatakan bahwa:

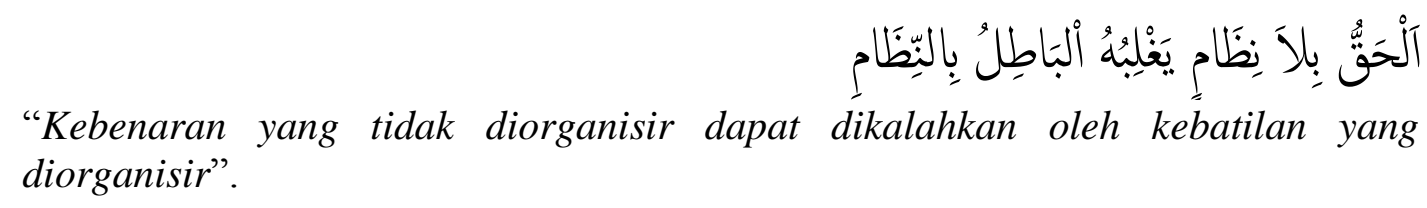

Perkataan beliau tersebut mengingatkan kita kembali tentang betapa pentingnya untuk seseorang ikut terlibat dalam berorganisasi. Karena kebenaran yang tidak terorganisir akan dapat dengan mudah dikalahkan oleh kejahatann yang terorganisir dengan baik.

\section{Pengertian Perilaku}

Memahami ilmu tentang perilaku organisasi ada baiknya diketahui juga pemahaman mengenai ilmu yang membahas sebuah perilaku (behavioral science). Semua persoalan tentang tindakan dari individu, organisme, sistem atau entitas buatan tersebut yang mempunyai hubungan terhadap diri sendiri ataupun lingkungan sekitarnya (Stephen $\mathrm{P}$ Robbins, 2006). Respons yang ada akan diperhitungkan dari sistem atau organisme ke berbagai macam rangsangan, baik internal ataupun eksternal, secara sadar ataupun tidak, 
bersifat terbuka atapun rahasia dan dilakukan secara sukarela ataupun juga tidak (S.p Malayu, H dan Hasibuan, 2014).

Perilaku yang merupakan cara melakukan sebuah tindakan dan memperlihatkan karakter dari semua individu, walaupun mungkin adanya perbedaan. Terdapat 3 asumsi berkaitan dengan perilaku, yaitu: a) caused, b) motivated, c) behavior is shown pada sasaran. Hal-hal tersebut berkaitan sebagai pondasi awal dari perilaku seseorang kepada siapa saja dan kapan saja (L. E. Ricou et al., 2000).

Setiap individu akan berperilaku ketika adanya sebuah rangsangan dan mempunyai sasaran tertentu. Perilaku kearah sasaran tersebut, timbul karena adanya rangsangan dan semua perilaku ada penyebabnya. Hal pokok ialah sebuah gap antara kondisi saat ini terhadap kondisi yang diharapkan. Rangsangan yang ada akan dipilih dari berbagai sistem yang mungkin bermacam-macam bentuknya. Untuk kejelasannya mengenai hal terdapat pada gambar dibawah ini.

\section{Gambar. 1}

Model Dasar Perilaku oleh Kast dan James

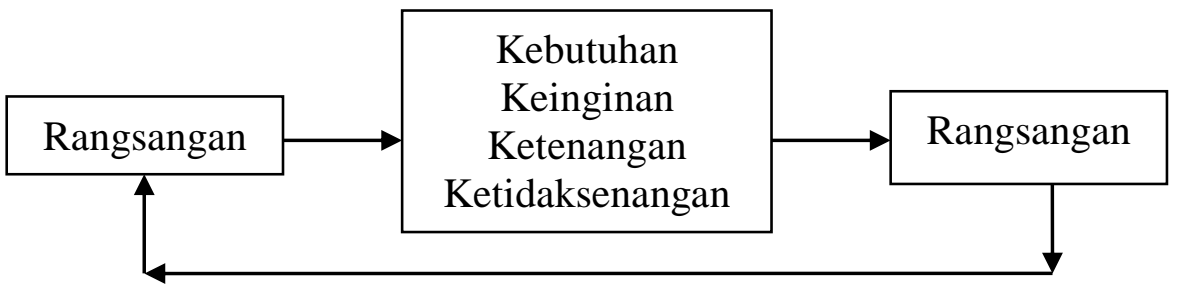

Terdapat juga didalam Q.S. Al-Anfal:46 yang Allah S.W.T. berfirman, yaitu:

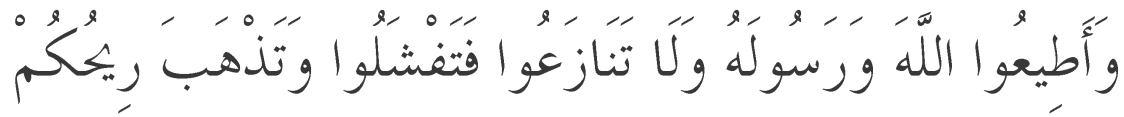

"dan taatlah kepada Allah dan Rasul-Nya dan janganlah kamu berbantahbantahan yang menyebabkan kamu menjadi gentar dan hilang kekuatanmu dan bersabarlah. Sesungguhnya Allah beserta orang-orang yang sabar".

Penjelasan ayat tersebut yang berkaitan dengan perilaku individu bahwasannya, dalam sebuah perilaku yang ada disetiap diri individu yang tentunya memiliki perbedaan satu dengan lainnya yang biasanya akan ada selisih paham menegani suatu hal. Berkaitan dengan perilaku tersebut, dalam sebuah organisasi diusahakan oleh setiap anggotanya untuk tidak tumbuhnya sebuah permasalahan yang akan menyebabkan sebuah permusuhan dan pada akhirnya menghancurkan kesatuan organisasi.

Dari beberapa uraian tersebut dapat dipahami bahwasannya perilaku itu sendiri ialah sebuah interaksi, tindakan dan/atau kegiatan seseorang mempunyai kaitan satu dengan yang 
lainnya dan interaksi tersebut ditentukan juga oleh adanya faktor internal maupun eksternal. Karena individu juga harus bisa dan mampu untuk berhasil mendapatkan semua tujuan dan keinginan dari kelompok/organisasi yang dimana seseorang ini telah menjadi bagian di dalam kelompok/organisasi tersebut.

\section{Pengertian Organisasi}

Organisasi sendiri mempunyai hubungan terhadap aspek sosial, karena sebuah subjek dan objek dari organisasi tersebut ialah individu yang telah memiliki ikatan oleh nilai kehidupan. Definisi dari makna organisasi adalah sekelompok orang-orang yang terikat secara formal dalam hubungan dan akan bekerjasama untuk sebuah tujuan Bersama (Ismail Nawawi Uha, 2013). Dalam Al-Qur'an sendiri, untuk mempelajari definisi dari organisasi itu sendiri dan kata tersebut ialah terdiri dari Shaff dan Ummat. Identifikasi dari makna kata Shaff yang berkaitan dengan pengertian organisasi ialah kumpulan yang memiliki sistem teratur dan juga tertib dalam mencapai sebuah keinginan. Sedangkan Ummat ialah mereka yang berada didalamnya untuk menjalankan perannya, guna tercapainya tujuan organisasi yang telah ditentukan. Berkaitan dengan firman Allah S.W.T. dalam Q.S. As-Shaff: 4, yakni:

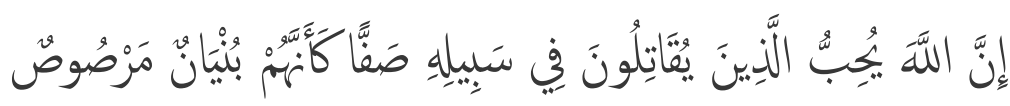

"Sesungguhnya Allah menyukai orang yang berperang dijalan-Nya dalam barisan yang teratur seakan-akan mereka seperti suatu bangunan yang tersusun kokoh".

Bermacam-macam pendapat tentang makna dari organisasi, ahli lain tentunya juga banyak berpendapat dan mengartikan dari penjabaran mengenai pengertian dari organisasi dan tentunya semua berbeda pandangan, meskipun maksud dan tujuan dari penjelasan para ahli tersebut sama. Terdapat definisi lain dari organisasi juga, yaitu:

a) Terdapat subsistem yang lingkungannya lebih luas,

b) Semua pengaturan berorientasi pada sasaran orang dan tujuan,

c) Subsistem teknik, peralatan dan fasilitas,

d) Orang-orang yang bekerja sama dalam aktivitas,

e) Subsistem psikososial,

f) Sistem manajerial yang terdiri dari perencanaan, pelaksanaan dan pengawasan (Marita Ahdiyana, 2011).

Terdapat penjelasan lainnya tentang pengertian dari organisasi itu sendiri yaitu terdapat dua bagian besar penjelasan ialah sebagai berikut:

a) Organisasi merupakan sebagai wadah ataupun tempat dan sebuah subsistem, 
b) Organisasi berarti sebuah pelaksanaan dari gambaran aktivitas yang akan, sedang, atau telah dilaksanakan oleh manusia yang bergabung dalam sebuah organisasi sosial dan bidang apapun (Taliziduhu Ndraha, 2015).

Lain halnya dalam memandang sebuah organisasi sebagai suatu proses interaksi dan dibangun melalui sebuah percakapan (Morissan, 2020). Hal ini menggabungkan berbagai macam teori, seperti teori linguistik, wacana dan organisasi. Organisasi memiliki karakteristik tertentu yaitu adanya individu, kelompok, struktur, tujuan, dan mempunyai hubungan dalam bagianya (Morissan, 2020). Ada pula faktor yang mempengaruhi terbentuknya sebuah organisasi, yaitu sebagai berikut:

a) Harus terdapat dua orang atau lebih untuk membentuk sebuah kelompok,

b) Terdapat komunikasi antara individu yang membentuk kelompok dan berinteraksi untuk saling memberikan informasi,

c) Adanya usaha untuk mencapai tujuan secara bersama (John M Ivancevich, Konopaske Robert, and Michel T Mtteson, 2006).

Karena organisasi ialah sebuah struktur dalam hubungan antar individu dan di rancang oleh mereka sendiri. Oleh sebab itulah dalam suatu organisasi banyak ketidaksempurnaan yang terdapat didalamnya. Tetapi sebuah organisasi dapat tumbuh dan berkembang melalui suatu skema yang didesain dan melalui keadaan yang tidak diatur. Pertumbuhan hal-hal yang didesain terlebih dahulu adalah suatu respons rasional terhadap sebuah tekanan dari dalam dengan tujuan untuk membentuk suatu hubungan kembali yang diperlukan secara fungsional (Ricou et al.).

Dari beberapa pengertian organisasi yang sebagaimana telah ada di atas pada hakikatnya mempunyai empat unsur pokok, seperti yang diungkapkan Nawawi Uha sebagai berikut:

a) Manusia

b) Filsafat

c) Proses

d) Tujuan

Mengenai hal tersebut bahwasannya dalam setiap organisasi terdapat orang-orang yang memiliki tanggung jawab dalam mengkoordinasikan orang lain yang akan berkerjasama. Sebuah peraturan yang harusnya disetujui secara bersama-sama, sering kali tidak dipahami oleh lainnya dan mungkin juga terpaksa untuk menyetujuinya. Dengan pengertian lainnya bahwa organisasi akan semakin menjadi kompleks, strukturnya semakin rumit, dan tingkat 
formalitas menjadi besar dari sebelumnya. Hal tersebut tentunya akan mempengaruhi individu dalam bekerjasama disebuah organisasi dan posisi dimensi dari manusia menjadi suatu hal yang sangat penting dalam organisasi.

1) Pengertian Perilaku Organisasi

Perilaku organisasi sebagai terjemahan dari organizational behavior adalah sebuah ilmu dalam area keterampilan jelas yang menyangkut berbagai aspek tindakan dari manusia dalam organisasi atau kelompok tertentu (Tahir). Aspek yang ditumbuhkan oleh sebuah pengaruh organisasi terhadap manusia dan juga sebaliknya yakni aspek dari pengaruh manusia terhadap organisasi. Tujuan praktisnya adalah untuk membuat bagaimana perilaku dari manusia tersebut dapat memberikan pengaruh dalam usaha pencapaian tujuan dari sebuah organisasi. Berkaitan dengan hal tersebut, maka perilaku organisasi yakni mempelajari tiga hal yang menjadi sebuah penentu dalam organisasi, yaitu individu, kelompok, dan struktur (Stephen P.Robbins and Timothy A.Judge, 2017).

Istilah dari Perilaku Organisasi sendiri mengandung arti "keterampilan bermasyarakat" yang dipergunakan secara luas (Supartha and Sintaasih). Setiap indvidu memiliki peranan dan merupakan aset terpenting yang harus ada, baik pada organisasi makro ataupun hingga ke mikro. Perilaku organisasi sendiri adalah sebuah bidang indispliner dan diperlihatkan untuk memberikan pemahaman, serta mengelola para pegawai yang lebih baik. Hal tersebut bermakna bahwa perilaku pada organisasi ialah berorientasi pada sebuah penelitian dan penerapan (Robert dan Kinicki Angelo Kreitner, 2014).

Sebuah konsep dari pengertian mengenai perilaku organisasi yang mengkaji perihal struktur, individu dan juga kelompok serta bertujuan dalam membenahi kefektivitasan organisasi (Supartha and Sintaasih). Studi yang membahas tentang perilaku organisasi dalam berbagai macam aspek tingkah laku dari individu yang terlibat dan hal tersebut pada akhirnya akan menjadi sebuah interaksi yang saling berhubungan. Oleh sebab itu, karena pada dasarnya perilaku organisasi yang berpusat khusus pada situasi dan berkaitan dengan pekerjaan, maka ia akan menekankan kepada perilaku dalam hubungannya dengan kinerja, tugas tanggung jawab, kehadiran, pergantian posisi pada pegawai, produktivitas, dan manajemen (Robbins).

Perihal lainnya juga dapat dipertimbangkan, antara lain:

a) Studi perilaku organisasi pada bagian-bagian yang mempunyai hubungan dari semua ilmu tingkah laku. 
b) Ilmu disiplin untuk mengenal bahwa individu dipengaruhi oleh bagaimana sebuah pekerjaan tersebut diatur dan siapa yang akan bertanggung jawab untuk pelaksanaannya.

c) Perilaku organisasi masih memusatkan pada kebutuhan manajer untuk dapat menjamin bahwa semua tugas pekerjaan di dalam organisasi bisa dijalankan (Ahdiyana).

Jikalau dalam karakteristik individu terintegrasi dengan karakteristik pada organisasi tersebut, tentu akan terwujud sebuah perilaku individu dalam organisasi (Ricou et al.). Dalam hal ini diartikan bahwasannya:

Keterangan:

$$
\mathbf{P}=\mathbf{F}(\mathbf{I}, \mathbf{L})
$$

P: Perilaku, F: Fungsi, I: Individu, L: Lingkungan

Ungkapan tersebut dapat dibaca sebagai berikut:

"Perilaku adalah suatu fungsi dari integrasi antara seseorang individu dengan lingkungannya".

Untuk dapat lebih jelasnya dalam memahami ungkapan tersebut, hal demikian terdapat dalam gambar model perilaku organisasi yakni sebagai berikut:

Gambar. 2

Model Perilaku Organisasi

\begin{tabular}{|l|}
\hline Karakteristik Individu \\
Kemampuan \\
Kebutuhan \\
Kepercayaan \\
Pengalaman \\
Pengharapan \\
dan lain sebagainya \\
\hline
\end{tabular}

\section{Karakteristik Organisasi}

Hierarki

Tugas-tugas

Wewenang

Tanggung Jawab

Sistem Reward

Sistem Kontrol

dan lain sebagainya

Perilaku Individu

Dalam Organisasi 
Pentinya berorganisasi untuk seseorang/individu juga dijelaskan oleh Allah Swt dalam frimannya di Q.S. An-Nisa':71, yaitu:

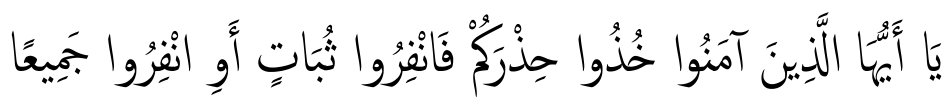

"Wahai orang-orang yang beriman! Bersiapsiagalah kamu, dan majulah (ke medan pertempuran) secara berkelompok, atau majulah bersama-sama (serentak)".

Dalam ayat tersebut bahwasannya Allah mengajarkan kepada ummat-Nya untuk menghadapi suatu kegiatan tentang apapun itu untuk dapat diselesaikan dengan cara berkelompok/berorganisasi. Karena dengan adanya sebuah organisasi, akan membuat perilaku individu lebih dapat terkontrol dan pencapaian semua tujuan akan lebih mudah diperoleh, karena semua kegiatan untuk mencapai tujuan tersebut dilakukan secara berkelompok/berorganisasi dan terasa lebih efektif dan efisien.

Dari penjelasan diatas mengenai pengertian tentang perilaku organisasi itu sendiri, dapat ditarik sebuah kesimpulan bahwasannya perilaku organisasi adalah mengendalikan tingkah laku individu-individu dalam organisasi dan perilaku tersebut nantinya dapat memberikan pengaruh bagi semua usaha dalam mencapai tujuan dari organisasi yang telah ditetapkan. Karena dalam hal pencapaian sebuah tujuan di organisasi ini, tentunya akan lebih efektif dan efisien bilamana dilakukan secara berkelompok/berorangisasi.

\section{Faktor-faktor yang Mempengaruhi Perilaku Organisasi}

Organisasi merupakan suatu kesatuan (entity) sosial yang dikoordinasikan secara sadar dengan sebuah batasan yang relative dapat di identifikasi dan bekerja atas dasar yang relatif terus menerus untuk mencapai tujuan bersama dan atau sekelompok tujuan. Organisasi juga dipandang sebagai suatu satuan sistem sosial untuk mencapai tujuan bersama dengan cara melalui usaha dalam sebuah kelompok. Untuk mengelola sumber daya manusia agar dapat bekerja secara efektif, tentunya perlu usaha untuk melakukan kegiatan manajemen kerja (managing work) dan manajemen orang (managing people) (http://repository.ut.ac.id/4581/1/EKMA5101-M1.pdf.). Fungsi yang berhubungan dengan manajemen kerja atau tugas ialah fungsi perencanaan, pengorganisasian dan pengendalian. Sedangkan untuk fungsi yang terkait dengan manajemen orang ialah berhubungan dengan pelaksanaan fungsi komunikasi, kepemimpinan dan motivasi. Dengan melakukan fungsi tersebut secara benar, maka orang-orang atau kelompok yang sedang bekerja sama akan dapat melakukan pekerjaan secara efektif dan efisien untuk mencapai tujuan dari organisasi 
itu sendiri. Meskipun dalam memahami sebuah perilaku individu merupakan suatu hal yang sulit, karena setiap individu tentunya memiliki perilaku yang berbeda-beda.

Ada beberapa faktor yang dapat mempengaruhi perilaku organisasi itu sendiri, diantaranya yaitu:

a) Peningkatan Kepuasan Kerja

Peningkatan kepuasan kerja dapat mempengaruhi perilaku individu dalam sebuah organisasi. Karena kepuasan kerja bagi individu dipengaruhi oleh hak-hak yang harus mereka dapatkan atas semua pekerjaan yang telah dilaksanakan.

b) Pengurangan Kealpaan

Tindakan dengan cara tidak masuk kerja yang dilakukan oleh individu terhadap organisasi atau sebuah perusahaan dapat memberikan pengaruh yang negatif terhadap efektifitas dan efisiensi kerja suatu organisasi.

c) Penurunan Turn Over

Turn over yang dimaksud ialah pengunduran diri para pekerja atau anggota dalam organisasi yang akan berpengaruh terhadap perilaku organisasi itu.

d) Peningkatan Produktifitas

Sebuah organisasi yang bisa dinyatakan produktif apabila organisasi ini mampu untuk mencapai tujuannya secara baik dan dianggap sesuai dengan target yang telah dilaksanakan. Baik target mengenai biaya, waktu dan tentunya hasil. Produktifitas dalam sebuah organisasi ini tentunya dapat mempengaruhi perilaku organisasi yang dimana produktifitas tersebut berkaitan erat dengan efektifitas dan efisiensi kinerja suatu organisasi (Ndraha).

Berkaitan dengan konsep perilaku organisasi itu sendiri ialah kinerja organisasi, karena perilaku individu dalam organisasi berhubungan dengan berbagai aktivitas dalam sebuah rantai nilai (value chain) yang terdapat pada organisasi (Supartha and Sintaasih). Terdapat juga berbagai faktor yang mempengaruhi perilaku organisasi dan didalam sebuah kinerja individu pada organisasi. Karena sesungguhnya hal ini dapat memberikan berbagai macam informasi mengenai prestasi dari unit-unit organisasi, dimana organisasi tentunya memerlukan penyesuaian-penyesuaian atau seluruh aktivitas sesuai dengan tujuan dari organisasi (Supartha and Sintaasih).

Perilaku organisasi juga akan sangat dipengaruhi oleh faktor internal (dari dalam) dan faktor eksternal (dari luar) yang dijelaskan sebagai berikut: 
a) Faktor internal (dari dalam) yang terdiri dari; Tujuan organisasi, Struktur organisasi, Sumber daya manusia, dan Budaya organisasi.

b) Faktor eksternal (dari luar) yang terdiri dari; Faktor politik, Faktor ekonomi, dan Faktor sosial (Tewolde Berhan Gebre Egziabher and Sue Edwards, 2013).

Dari beberapa penjelasan tersebut, dapat dikatakan bahwa ada begitu banyak faktorfaktor dalam mempengaruhi perilaku organisasi. Ada yang mempersoalkan tentang peralatan, sarana dan prasarana, ataupun teknologi yang dianggap sebagai salah satu faktor dominan, terlebih lagi dalam penelitian ini mengenai akreditasi yang semula biasanya dilaksanakan secara langsung/tatap muka (face to face) antara pihak terkait dengan asesor, kini dilaksanakan secara Daring yang semuanya menggunakan teknologi. Bahkan ada juga yang mepersoalkan kualitas sumber daya manusia, mekanisme pekerjaan, dan budaya organisasi serta efektivitas kepemimpinan yang ada dalam organisasi tersebut. Dengan demikian dapat katakan bahwa perilaku organisasi akan selalu dipengaruhi oleh berbagai faktor, baik faktor internal dan faktor eksternal yang memang terdapat didalam sebuah organisasi manapun dan dalam bentuk apapun.

\section{Akreditasi Program Studi}

Secara terminologi akreditasi didefinisikan sebagai suatu proses penilaian kualitas yang menggunakan kriteria baku mutu yang telah di tetapkan dan bersifat terbuka (Rika Puspa Dewi, 2010). Sedangkan Permenristekdikti Nomor 32 Tahun 2016 tentang Akreditasi Program Studi dan Perguruan Tinggi, mengatakan bahwa akreditasi ialah kegiatan penilaian untuk menentukan kelayakan pada Program Studi dan Perguruan Tinggi.

Akreditasi merupakan sebuah proses dan adanya hasil. Sebagai sebuah proses, akreditasi ialah suatu upaya BAN-PT untuk melakukan penilaian dan menentukan status mutu dari Program Studi di Perguruan Tinggi yang berdasarkan pada semua standar ketetapan mutu yang telah ada. Sedangkan sebagai hasil, akreditasi adalah status mutu yang di peroleh Program Studi pada Perguruan Tinggi dan hasilnya akan diumumkan kepada masyarakat secara luas (A Al Idrus, K Karnan, and D Setiadi, 2019: 211-216). Seperti halnya kebanyakan masyarakat umum yang memahami tentang akreditasi pada lembaga pendidikan, mereka akan menilai kualitas dari Program Studi (Prodi) atau Perguruan Tinggi (PT) tersebut dilihat dari hasil akreditasinya. Akreditasi Program Studi dan Perguruan Tinggi dibedakan menjadi empat yaitu sebagai berikut: 1) Terakreditasi, 2) Terakreditasi Cukup (C), 3) Terakreditasi Baik (B) dan 4) Terakreditasi Amat Baik (A). 
Untuk menghasilkan sistem pendidikan yang berkualitas, maka perguruan tinggi tentunya mempunyai kewajiban berupa tanggung jawab untuk menjaga kelayakan setiap program studi atau jurusannya dalam menyelenggarakan kegiatan akademik. Dalam penentuan sebuah kelayakan pada program satuan pendidikan tersebut, tentunya harus berdasarkan kriteria yang telah ada dan ditetapkan untuk kemudian dilakukan melalui sebuah kegiatan akreditasi. Oleh sebab itu, setiap program studi telah diwajibkan untuk mengusulkan proses penilaian kelayakan yan kemudian akan dilaksanakan berdasarkan tahapan-tahapan yang tercantum dalam Peraturan Menteri Pendidikan dan Kebudayaan Republik Indonesia Nomor 87 Tahun 2014 tentang Akreditasi Program Studi dan Perguruan Tinggi.

Adapun tujuan dilakukannya kegiatan Akreditasi seperti yang diungkapkan (Fawaz Hilmy 2016) pada Program Studi dan Perguruan Tinggi ialah sebagai berikut:

a) Menentukan kelayakan Program Studi dan Perguruan Tinggi berdasarkan kriteria yang mengacu pada Standar Nasional Pendidikan Tinggi.

b) Menjamin mutu Program Studi dan Perguruan Tinggi secara eksternal, baik dibidang akademik maupun non akademik untuk melindungi kepentingan mahasiswa dan masyarakat.

c) Mendorong peningkatan atau perbaikan mutu pendidikan tinggi secara berkelanjutan.

Program studi akan menyusun sebuah Borang Akreditasi Institusi dan Perguruan Tinggi (AIPT) dan juga evaluasi diri sesuai dengan standar-standar yang telah ditentukan dalam pedoman penyusunan. Standar akreditasi pada program studi sarjana dan pascasarjana, mencakup sebuah komitmen untuk memberikan layanan prima dan efektivitas pendidikan yang terdiri atas tujuh standar, yaitu sebagai berikut:

a) Standar I: Visi, Misi, Tujuan, Sasaran, dan Strategi Pencapaian

b) Standar II: Tata Pamong, Kepemimpinan, Sistem Pengelolaan, dan Penjaminan Mutu

c) Standar III : Mahasiswa dan Lulusan

d) Standar IV: Sumber Daya Manusia

e) Standar V: Kurikulum, Pembelajaran, dan Suasana Akademik

f) Standar VI: Pembiayaan, Sarana dan Prasarana serta Sistem Informasi

g) Standar VII: Penelitian, Pelayanan/Pengabdian kepada Masyarakat dan Kerjasama

Standar-standar tersebut menggambarkan suatu proses organisasi pendidikan tinggi yang mencakup input, proses dan output/outcame, sehingga mutu dari program studi ataupun perguruan tinggi dapat dilihat dari keseluruhan dalam melaksanakan kewajibannya 
yaitu Tridharma Perguruan Tinggi. Core business dari sebuah perguruan tinggi sebagai lembaga pendidikan tidak bisa dilakukan dengan efektif tanpa adanya dukungan dari aspek organisasi dan manajemen, sehingga menjadikan hal ini penting dalam sebuah penjaminan mutu suatu perguruan tinggi untuk mewujudkan visi, melaksanakan visi serta mencapai tujuan yang telah ditetapkan sebelumnya. Karena banyaknya unsur-unsur yang terdapat disetiap standar-standar yang ada dan harus disertakan didalam borang akreditasi, tak jarang akan banyak terjadi kesalahan serta kesulitan dalam penyampaian informasi di borang tersebut, terutama dalam proses pengisian yang dilakukan (K.Y.E. Aryanto and I.K.R Arthana, 2016): 1-7). Tentu saja dalam proses kegiatan akreditasi yang dilakukan tersebut akan melalui beberapa tahapan, mulai dari tahap proses persiapan, pelaksanaan dan setelah pelaksanaan kegiatan akreditasi tersebut. Pada tahapan proses persiapan akreditasi ini, tentunya dibutuhkan banyak tenaga, pikiran dan waktu untuk menyelesaikannya. Apalagi dalam proses penginputan data yang dapat dilakukan bukan hanya sekali saja atau dalam kurun waktu tertentu saja. Dalam proses penginputan data ini harus selalu dilakukan kapanpun dan di manapun. Proses tersebut diperlukan karena akreditasi dilaksanakan bukan hanya sekali, namun selalu dilakukan dalam kurun waktu selama lima tahun sekali. Maka dari hal tersebut, seharusnya aktivitas untuk mengupload data dilaksanakan dengan meniadakan batasan waktu pengumpulan (Seminar Nasional Penelitian, 2020: 296-300). Sebagai salah satu bentuk upaya untuk dapat memaksimalkan pengumpulan data tersebut, maka link form yang dikhsuskan untuk format pengisian harus dibuat dengan mempertimbangkan kemudahan, efisien dan efektif dalam penggunaannya.

Idealnya dalam pengisian data-data borang tentunya harus mempunyai kesinkronan antara data pada borang program studi, fakultas, dan institusi. Dengan kondisi tersimpannya data-data yang tersebar di masing-masing satuan unit/lembaga juga akan menjadi salah satu permasalahan dalam penyusunan boranag tersebut. Menangapi hal ini, tentunya dibutuhkan sebuah individu-individu yang harus dibentuk dalam suatu kelompok/organisasi agar dapat melakukan kerjasama yang baik dalam persiapan, penyusunan dan penginputan data yang optimal, guna untuk mendukung semua proses pelaksanaan akreditasi yang baik untuk program studi. Dalam membangun sebuah kerjasama di kelompok/organisasi, diperlukan adanya strategi yaitu seni memadukan atau menginteraksikan antara faktor kunci keberhasilan agar terjadinya sinergi dalam mencapai suatu tujuan dan strategi merupakan sarana mencapai tujuan tersebut. Alokasi sumberdaya yang memampukan organisasi ini dapat memberikan kemudahan bahkan meningkatkan kinerjanya. Konsep kinerja dari 
sumberdaya yang memampukan organisasi ialah kuantitas, kualitas, dan ketepatan waktu dalam menyelesaikan pekerjaan (Arifin Suking and Megi Yusuf Hamid, 2019: 35-44). Individu yang memiliki karakter dan perilaku seperti inilah didalam sebuah kelompok/organisasi yang dapat membantu penyelesaian data-data borang akreditasi dengan baik dan selama proses persiapan, pelaksanaan hingga selesainya akreditasi.

Dengan demikian dapat dikatakan bahwa, pentingnya sebuah akreditasi pada program studi bukannya hanya untuk menentukan kualitas dari program studi saja, melainkan juga akan sangat mempengaruhi pada instansi/lembaga, anime masyarakat dalam memilih untuk melanjutkan pendidikannya, alumni dari program studi, pengguna alumni yang terkait dan lain sebagainya. Terlepas dari semua hasil yang akan diperoleh, tentunya ada faktor penting selama proses tahapannya, mulai dari persiapan, pelaksanaan dan setelah pelaksanaan dari kegiatan akreditasi, ialah individu-individu yang terlibat dalam kegiatan akreditasi yang sebelumnya telah dibentuk berupa tim/kelompok/organisasi pada kegiatan akreditasi tersebut.

\section{METODE}

Penelitian ini menggunakan metode penelitian kualitatif dengan teknik pengumpulan data yang diperoleh melalui participant observation, in-depth interview dan documentation. Penelitian dilakukan pada Program Studi Administrasi Pendidikan Fakultas Keguruan dan Ilmu Pendidikan (FKIP) Universitas Muhammadiyha Palembang. Informasn dalam penelitian ini adalah Dekan, Wakil Dekan I sampai IV, Ketua dan Sekertaris Program Studi, Dosen, Mahasiswa, Alumni, Stakeholder (Pengguna Alumni), Tim Borang Akreditasi Fakultas dan Program Studi, serta Unit Penjamin Mutu (UPM). Untuk menjamin keabsahan data dalam penelitian ini ialah menggunakan teknik trianggulasi yaitu trianggulasi sumber, teknik dan waktu. Dalam analisis data dilakukan secara interaktif dan berlangsung secara terus menerus sampai tuntas, sehingga datanya sudah jenuh dan analisis datanya yaitu data reduction, data display, dan conclusion drawing/verification.

\section{HASIL PENELITIAN DAN PEMBAHASAN}

Universitas Muhammadiyah Palembang ialah sebagai salah satu lembaga pendidikan yang bergerak di bidang jasa dalam tingkat satuan pendidikan pada Perguruan Tinggi dan menjadi sebagai salah satu Perguruan Tinggi Swasta yang terdapat di Kota Palembang. Pada semua tingkat satuan pendidikan terdapat sebuah kegiatan yang dikhususkan untuk 
menilai kualitas dari lembaga pendidikan, ternasuk juga di Perguruan Tinggi Negeri ataupun Swasta. Kegiatan yang dimaksud ialah berupa Akreditasi, yang mana dalam kegiatan tersebut mempunyai tujuan untuk menilai sebuah kulitas (Kelayakan pada Program Studi dan Perguruan Tinggi) menggunakan kriteria-kriteria baku mutu yang telah ditetapkan dan juga tentunya bersifat terbuka dalam Permenristekdikti Nomor 32 Tahun 2016 tentang Akreditasi Program Studi dan Perguruan Tinggi. Akreditasi tersebut harus terus dilaksanakan sesuai dengan peraturan dan kurun waktu yang telah ditetapkan.

Terdapat perbedaan dari kegiatan Akreditasi saat sekarang ini, terkhusus dimulai pada Tahun 2020 tersebut bahwasannya pelaksanaan dari kegiatan Akreditasi ini akan dilakukan dengan cara Daring bukan secara Luring. Penggunaan dari sistem ini dapat dikatakan terpaksa dan harus dilakukan, karena disemua Negara termasuklah Indonesia masih terjangkit hebat dengan wabah dari sebuah Virus Covid-19. Sehingga BAN-PT membuat kebijakan baru dalam proses pelaksanaan Asesmen Lapangan ini. Merujuk pada ketentuan Pasal 1 angka 1 Peraturan BAN-PT Nomor 5 Tahun 2020, maka DE BAN-PT mengambil langkah untuk pelaksanaan Asesmen Lapangan secara Daring. Berkaitan dengan hal tersebut, DE juga telah menyusun Panduan Asesmen Lapangan secara Daring sesuai dengan kebutuhan dan kriteria penilaian sebagaimana yang diatur dalam instrumen akreditasi yang digunakan. Panduan ini dimaksudkan sebagai bahan acuan dan panduan bagi panel asesor untuk melaksanakan Asesmen Lapangan secara Daring (BAN-PT, "Panduan Asesmen Lapangan Secara Daring).

Pada wawancara yang telah dilakukan secara langsung bersama Dekan yaitu Bapak Dr. H. Rusdy A. Siroj, M.Pd., sebelum peneliti masuk dalam berbagai macam pertanyaan yang telah disiapkan, beliau memberikan informasi mengenai kegiatan Akreditasi dan mengatakan bahwasannya "Akreditasi yang rutin dilaksanakan ini mempunyai jangka waktu yang telah ditentukan pada Tujuh Program Studi yang terdapat di sini dan tentunya memiliki hasil yang akan berdampak serta berpengaruh pada kualitas ataupun progress dari Program Studi, Fakultas hingga ke Universitas".

Dari Observasi oleh peneliti ada Dua Program Studi yang melaksanakan kegiatan Akreditasi Asesmen Lapangan secara Daring dimasa Pandemi Covid-19 ini dan salah satu diantaranya ialah Program Studi Administrasi Pendidikan. Berkaitan dengan hal tersebut, ada beberapa individu yang dilibatkan pada pelaksanaan kegiatan Akreditasi secara Daring ini, mereka akan ditugaskan dan dibentuk dalam sebuah Tim Borang Akreditasi yang dibuatkan berupa Surat Tugas langsung oleh Dekan untuk dapat mempersiapkan dan 
menjalankan dengan baik semua rangkaian dari kegiatan Akreditasi secara Daring tersebut, mulai dari persiapan semua Data Borang 3A (Program Studi) dan Borang 3B (Fakultas) secara teliti dan pelaksanaan Akreditasi yang akan dilakukan secara Daring pada Program Studi yang bersangkutan (Lampiran: Surat Tugas Dari Dekan” (n.d.).

1. Proses Persiapan Akreditasi secara Daring

a. Mempunyai Prinsip Manajemen untuk sebuah kegiatan yang dapat dikatakan baik oleh peneliti, karena dalam melaksanakan sebuah kegiatan terlebih dahulu Dekan dan jajarannya sebagai pemimpin membuat Planning (Perencanaan) yaitu dengan cara merencanakan semua hal tentang apa saja yang dibutuhkan untuk kegiatan Akreditasi yang dilakukan melalui rapat internal pimpinan. Dari rapat tersebut salah satunya menghasilkan kesepakatan untuk membentuk sebuah Organizing (Organisasi) yaitu Tim Borang Akreditasi yang didalamnya terdapat kejelasan melalui Hierarki (Tingkatan) dengan pembagian wewenang, tugas dan tanggung jawab untuk semua anggota yang terlibat.

b. Pemilihan untuk siapa saja individu yang akan dilibatkan dan memberikan kriteria perilaku yang harus dimiliki oleh individu tersebut menjadikan langkah yang baik agar Tim Borang Akreditasi yang telah dibentuk dalam melaksanakan semua proses persiapan dan dalam Manajemen disebut dengan Actuating (Proses Implementasi Rencana) untuk kegiatan Akreditasi sehingga semua persiapan yang dilakukan dapat terlaksana lebih efektif dan efisien.

c. Dilakukannya sosialisasi terlebih dahulu oleh Dekan dan lainnya terkait dengan pelaksanaan kegiatan Akreditasi yang akan menggunakan Sistem Daring (Dalam Jaringan) dan bukan seperti biasanya sebelum Pandemi dari Virus Covid-19. Hal ini menjadikan proses persiapan dapat dilakukan dengan baik dan teliti oleh Tim Borang Akreditasi, meskipun individu yang terlibat harus mempersiapkan waktu, tenaga dan fikiran lebih ekstra.

d. Adanya Controlling yang dilakukan untuk pekerjaan di Tim Borang Akreditasi melalui Briefing dan Grup WhatsApp, sehingga semua anggota yang terlibat dapat selalu mengevaluasi setiap tugas seperti kendala persiapan, evaluasi data dan lain sebagainya.

e. Terdapat Team Work yang baik dalam melaksanakan semua proses persiapan untuk kegiatan Akreditasi tersebut.

\section{Saat Pelaksanaan Akreditasi secara Daring}


a. Pelaksanaan dari kegiatan Asesmen Lapangan yang dilakukan selama dua hari tersebut, secara keseluruhan berjalan dengan baik tanpa hambatan ataupun kendala teknis dalam penggunaan media untuk pelaksanaan secara Daring.

b. Ada banyak kecemasan dan kekhawatiran yang terjadi didalam diri setiap individu yang terlibat, meskipun kegiatan Akreditasi tersebut dilaksanakan dengan menggunakan Sistem Daring.

c. Kerjasama Tim (Team Work) yang terbukti baik pada saat pelaksanaan kegiatan tersebut berlangsung, penurunan ego dalam diri masing-masing individu terlihat pada saat terjadinya hambatan tentang sebuah berkas, anggota yang lain bukan menyalahkan ataupun membiarkan individu tersebut seorang diri terkait tugas dan tanggung jawabnya, melainkan turun tangan langsung untuk mencari perihal berkas yang dibutuhkan pada saat itu.

d. Persiapan yang telah dilakukan secara maksimal, baik berupa waktu, tenaga dan fikiran yang terbilang ekstra dari Tim Borang Akreditasi. Saat pelaksanaan tersebut yang mereka fikirkan bukan tentang perolehan hasil, melainkan tentang kelancaran dari proses saat pelaksanaan kegiatan Asesmen Lapangan berlangsung. Tim Borang Akreditasi yakin bahwa hasil yang didapatkan tidak akan mengkhianati sebuah proses persiapan.

\section{Setelah Pelaksanaan Akreditasi secara Daring}

a. Setelah pelaksanaan seluruh rangkaian kegiatan selesai mempunyai evaluasi data yang dianggap Aseseor masih kurang dan harus diperbaiki.

b. Adanya kecemasan ataupun kekhawatiran dari beberapa individu dalam Tim Borang Akreditasi perihal sebuah harapan untuk hasil Akreditasi yang akan diperoleh.

c. Ada rasa keyakinan tersendiri dari beberapa individu dalam Tim Borang Akreditasi bahwa hasil yang akan didapatkan pasti menjadi yang terbaik, sesuai dengan waktu, tenaga dan fikiran ekstra yang sudah diberikan untuk seluruh proses pelaksanaan kegiatan.

d. Adanya perasaan bahagia, bangga, terharu dari Tim Borang Akreditasi ketik memperoleh hasil yang sesuai dengan harapan semuanya.

e. Terdapat harapan-harapan yang lebih baik lagi dan menjadi sebuah beban juga, karena diharuskan mampu untuk membuktikan bahwa perolehan hasil Akreditasi A memang layak didapatkan karena sesuai dengan kondisi yang sebenarnya. 
4. Faktor Pendukung yang Mempengaruhi Perilaku Organisasi

a. Pemilihan individu untuk persamaan karakteristik perilaku yang akan dilibatkan dalam Tim Borang Akreditasi, dilakukan oleh Dekan.

b. Kepemimpinan seperti pemberian motivasi dari ketua Program Studi dan Dekan Fakultas, karena dapat mengendalikan anggota untuk bisa bekerja sesuai dengan standar dan tujuan dari organisasi.

c. Sosialisasi yang diberikan terlebih dahulu kepada anggota organisasi sebelum mempersiapkan dan melaksanakan semua rangkaian kegiatan.

d. Teknologi, sarana dan prasarana yang mendukung semua pelaksanaan kegiatan untuk Akreditasi secara Daring.

e. Kualitas linkungan kerja yang tersedia seperti keselamatan kerja, kebersihan dan alat pelengkap untuk protokol kesehatan (masker, hand sanitizer, hand wash dan lain sebagainya).

f. Kontrol kerja dan evaluasi yang dilakukan melalui rapat dan sebuah grup di sosial media seperti WhatsApp Messenger.

g. Team Work yang terbentuk antar individu dalam organisasi, berkaitan dengan kinerja mereka dan sebagai umpan balik untuk mengetahui setiap masalah, hambatan ataupun kendala yang terjadi.

h. Reward (Penghargaan) yang diberikan kepada Tim Borang Akreditasi sebagai bentuk apresiasi atas waktu, tenaga dan fikiran yang secara ekstra telah diberikan oleh seluruh anggota organisasi.

5. Faktor Penghambat yang Mempengaruhi Perilaku Organisasi

a. Banyak rasa kekhawatiran yang dimiliki oleh individu dalam Tim Borang Akreditasi, karena Program Studi Administrasi Pendidikan menjadi yang pertama melaksanakan kegiatan Akreditasi secara Daring, sehingga sering ada rasa takut dan tidak percaya diri.

b. Keterbatasan waktu dalam mempersiapkan semua data yang diperlukan karena bersamaan dengan kegiatan akademik dan kewajiban pekerjaan lainnya.

c. Bukti fisik seperti dokumen dan foto kegiatan yang letaknya tidak beraturan bahkan terkadang tidak ada karena banyak kegiatan telah dilakukan tetapi lupa untuk mendokumentasikannya.

d. Ada beberapa fasilitas yang kurang memadai selama proses persiapan hingga ke tahapan untuk pelaksanaan kegiatan Akreditasi tersebut, yaitu peralatan berupa media 
elektronik seperti printer, layar proyektor, jaringan internet dan individu yang ahli dalam bidang informatika untuk pelaksanaan kegiatan Akreditasi secara Daring.

e. Kurangnya komunikasi terhadap pihak-pihak yang akan dilibatkan dalam pelaksanaan kegiatan Asesmen Lapangan seperti Stakeholder (Pengguna Alumni), Alumni dan Mahasiswa.

f. Adanya Dosen yang telah pensiun dan Mahasiswa Stop Out tanpa adanya kejelasan, sehingga sulit untuk menyamakan data yang ada didalam Borang 3A (Program Studi).

\section{KESIMPULAN}

Perilaku organisasi ialah sebuah pelaksanaan kendali pada tindakan individu-individu di organisasi dan proses dari tindakan tersebut dapat memberikan pengaruh dalam mencapai tujuan organisasi yang telah ditetapkan. Karena dalam hal pencapaian sebuah tujuan di organisasi ini, dapat lebih efektif dan efisien bilamana dilakukan secara berkelompok/berorangisasi. Oleh sebab itu individu-individu yang diikutsertakan untuk terlibat didalam kegiatan Akreditasi secara Daring pada Program Studi Administrasi Pendidikan adalah mereka yang memang memenuhi semua kriteria ideal dari Pimpinan. Karena perolehan hasil dari kegiatan Akreditasi ini akan memberikan dampak baik untuk kemajuan dari Instansi (Lembaga) yang bersangkutan. Pencapaian tujuan berupa hasil dari kegiatan Akreditasi yang diinginkan, maka banyak hal yang memang dilakukan berkaitan dengan perilaku organisasi dalam Tim Borang Akreditasi tersebut.

\section{DAFTAR PUSTAKA}

Ahdiyana, Marita. (2011). DIKTAT - Perilaku Organisasi. Universitas Negeri Yogyakarta http://staffnew.uny.ac.id/upload/197303182008122001/pendidikan/diktat-perilakuorganisasi.pdf.

Aryanto, K.Y.E., and I.K.R Arthana. (2016). Sistem Informasi Penyusunan Borang Akreditasi Daring Untuk Program Studi Diploma, Sarjana Dan Fakultas. Seminar Nasional Vokasi dan Teknologi (SEMNASVOKTEK): 1-7.

BAN-PT. (2020). Panduan Asesmen Lapangan Secara Daring.

Dewi, Rika Puspa. (2010). Hubungan Pengetahuan Mengenai Akreditasi Rumah Sakit Dan Karakteristik Individu Dengan Kinerja Perawat Rumah Sakit Zahirah Tahun 2010. Thesis.

Egziabher, Tewolde Berhan Gebre, and Sue Edwards. (2013). “済無No Title No Title.” Africa's potential for the ecological intensification of agriculture, 53(9): 1689-1699.

Eva, Khoirunnisa. (2018). Analisis Pengaruh Akreditasi Program Studi Terhadap Intensitas Belajar Dan Harapan Masa Depan. At-Taqaddum, 10(2). 
Fitri, FITRI. (2018). Perilaku Organisasi Dan Kepemimpinan Sebagai Sebuah Sistem.” Adaara: Jurnal Manajemen Pendidikan Islam, 6(1): 484-497.

Hilmy, Fawaz, Siti Atia, Syifa Fauziah, and Ulfha Sapitri. (2016). Sistem Akreditasi Prodi Dan Sitem Akreditasi Institusi.

Idrus, A Al, K Karnan, and D Setiadi. (2019). Analisis Kesiapan Akreditasi Berbasis SAPTO Program Studi Pendidikan Biologi Universitas Mataram.” Jurnal Ilmiah Profesi Pendidikan, 3(2): 211-216. https://scholar.google.com/citations?view_op=view_citation\&hl=en\&user=cc76O8M AAAAJ\&pagesize=100\&citation_for_view=cc76O8MAAAAJ:hqOjcs7Dif8C.

Ivancevich, John M, Konopaske Robert, and Michel T Mtteson. (2006). Perilaku Dan Manajemen Organisasi. Jakarta: Erlangga.

Junaidah, and Sovia Mas Ayu. (2019). Kata Kunci $\square$ : Strategi Kerjasama, Akreditasi Prodi." Al-Idarah: Jurnal Kependidikan Islam, 9(2).

Kreitner, Robert dan Kinicki Angelo. Perilaku Organisasi. Ke-9. Jakarta: Salemba Empat, 2014.

Malayu, H dan Hasibuan, S.p. (2014). Manajemen Sumber Daya Manusia. Ke-18. Jakarta: PT Bumi Aksara.

Morissan. (2020) Komunikasi Organisasi. Ke-1. Jakarta Timur: Prenadamedia Group.

Muhammad, Arni. (2011). Komunikasi Organisasi. Ke-12. Jakarta: Bumi Aksara.

Nawawi Uha, Ismail. (2013). Budaya Organisasi Kepemimpinan \& Kinerja. Pertama. Jakarta: Kencana Prenadamedia Group.

Ndraha, Taliziduhu. (2005). Teori Budaya Organisasi. Pertama. Jakarta: PT Rineka Cipta.

P.Robbins, Stephen, and Timothy A.Judge. (2017). Perilaku Organisasi (Organizational Behavior). Ke-16. Jakarta: Salemba Empat.

Penelitian, Seminar Nasional. (2020). Sistem Pengelolaan Borang Akreditasi Berbasis Big Data, 1(2): 296-300.

Pt, Pada, Perkebunan Nusantara, and I I Persero. (2017). Pengaruh Perilaku Organisasi Terhadap Prestasi Karyawan Pada Pt. Perkebunan Nusantara Ii (Persero) Medan Tiur Rajagukguk, 3(2). http://repository.ut.ac.id/4581/1/EKMA5101-M1.pdf.

Ricou, L. E., J. P. Burg, I. Godfriaux, and Z. Ivanov. (2000). Rhodope and Vardar: The Metamorphic and the Olistostromic Paired Belts Related to the Cretaceous Subduction under Europe: Reply to Ivan Zagorchev's Comment 'Rhodope Facts and Tethys SelfDelusions. Geodinamica Acta, 13(1): 61-63.

Robbins, Stephen P. (2015). Perilaku Organisasi.

Robbins, Stephen P. (2006). Perilaku Organisasi Jakarta:” Indeks Kelompok Gramedia 10.

Suking, Arifin, and Megi Yusuf Hamid. (2019). Evaluasi Kinerja Alumni Dalam Mendukung Penguatan Akreditasi Program Studi. Jurnal Manajemen dan Supervisi Pendidikan, 4(1): 35-44.

Supartha, Wayan gede, and Desak Ketut Sintaasih. (2017). Pengantar Perilaku Organisasi; Teori, Kasus Dan Aplikasi Penelitian. Universitaa Udayana,. https://simdos.unud.ac.id/uploads/file_pendidikan_1_dir/b9ca64feeb1d962d5d06f51ea 4d7577b.pdf. 
Tahir, Arifin. (2014). Perilaku Organisasi. Edited by Sardi Salim. Yogyakarta: Deepublish.

Thoha, Miftha. (2004). Perilaku Organisasi (Konsep Dasar Dan Aplikasinya). Ke-15. Jakarta: PT Raja Grafindo Persada.

Yusuf Hamali, Arif. (2018). Pemahaman Manajemen Sumber Daya Manusia. Jakarta: CAPS (Center for Academic Publishing Service).

Yuyun, Yulianingsih. (2017). Manajemen Akreditasi Program Studi Pada Perguruan Tinggi. Al-Idarah: Jurnal Kependidikan Islam. 